\title{
Vermicomposting of terrestrial weeds Lantana camara L. and Parthenium hysterophorus L.: agriculture solid waste
}

\author{
Chander Kumar Singh*, Anand Kumar \\ Department of Energy and Environment, TERI University, New Delhi 110070, India, \\ *e-mail: chander.singh@teriuniversity.ac.in
}

Received: 18 October 2017 / Accepted: 21 November 2017

\begin{abstract}
The objective of this study was to determine the feasibility of vermicomposting of two noxious terrestrial weeds Lantana camara L. and Parthenium hysterophorus L. A plastic crate was used to design a compost pit and both weeds were mixed in the 1:1 ratio. Five different concentrations of weed mixture and cow dung were prepared and Eisenia fetida (Savigny, 1826) was used for vermicomposting. Physicochemical parameters of samples were analysed after 45, 60 and 90 days. Several physicochemical characteristics, important in terms of fertility, were measured in all treatments. A decrease in $\mathrm{pH}$, conductivity and total organic carbon was observed in all experimental pits during the 90-day cycle. An increase in the concentration of total nitrogen, potassium, sodium, and phosphorus was also observed. The results indicated that Parthenium and Lantana can be used as raw material along with cow dung for vermicomposting.
\end{abstract}

Key words: Parthenium hysterophorus, Lantana camara, Eisenia fetida, vermicomposting, nutrients.

\section{Introduction}

The Indian economy is based on agriculture. In recent years, the major problem has been the spread of a large number of terrestrial weed species in arable lands, pastures, grasslands and forests. Lantana camara L. (Lantana) and Parthenium hysterophorus L. in croplands have become a major concern for sustainable agriculture and public health. These weeds affect the biodiversity, cause ecological imbalance and, in the long run, affect soil productivity (Partel, 2011; Singh \& Beck, 2006). P. hysterophorus (locally known as carrot grass, congress grass) was introduced along with PL 480 Mexican wheat seeds, which gradually spread to every corner of the country (Kaur et al., 2014). L. camara is a species from the family Verbenaceae that was first introduced in India as an ornamental flowering plant and has since spread in most terrestrial ecosystems including forests, wetlands, and or- chards (Ghisalberti, 2000). Lantana is an evergreen, climbing shrub, strongly branched, usually 2-4 m high (Patel, 2011). Both weeds spread very fast and occupy large areas and adversely effects the flora and fauna of a given habitat. It is estimated that Parthenium has reduced the crop productivity by about $40 \%$ in India alone (Yadav \& Garg, 2011). Habitat colonisation by Parthenium is very fast, because the plant contains phenolics and lactones, i.e. parthenin, coronopilin, hysterin, ambrosin, ferulic and anisic acids (Kaur et al., 2014; Reinhardt et al., 2009). These toxic chemicals restrict the growth of other species in the region. It also provides shelter for a number of crop pests and vectors for human diseases (Nguyen et al., 2010; Sharman et al., 2009). This weed has been considered as one of the greatest sources of dermatitis, asthama, nasaldermal and naso-bronchial types of diseases (Morin et el., 2009; Akter \& Zuberi, 2009; Lakshmi \& Srinivas, 2007). Forest areas exposed to anthropogenic disturbances, such 
as grazing and deforestation, have been invaded by invasive alien species such as Lantana, Mikania, Chromolaena and Ageratinav (Love et al., 2009). Lantana has many adverse effects on forest ecosystems, including the loss of native biodiversity, replacement of native plant communities in forests ecosystems by dense impenetrable thickets, contribution to soil erosion and fire hazard, negative impact on forest regeneration, harbouring vectors that carry infectious diseases (Mellow et al., 2005; Sharma et al., 1988; Deshmukhe et al., 2011). Studies suggest that Lantana is also useful for methane gas production as it contains large amounts of holocellulose that can serve as low-cost feedstock for bioethanol production (Ganesh et al., 2008). It has a chitinase enzyme that can be used in agriculture, industry, environmental protection and chito-oligosaccharide production (Patel, 2011). Two new triterpenoids have been isolated from the roots of $L$. camara. Leaves of $L$. camara provide an essential oil that is rich in sesquiterpenes, while hepatoprotective oleanolic acid is isolated from its roots (Misra \& Laatsch, 2000). It has antipyretic, antimicrobial and antimutagenic properties and therefore it is used in folk medicine (Mello et al., 2005; Sharma, 1984; Sharma et al., 1988). The under-canopy soil covered with Lantana has high concentration of nutrients, indicating that the plant may be useful for improvement of soil fertility (Osunkoya \& Perrett, 2010).

The lack of natural enemies of these weeds helps them to grow fast and colonize. Available manual methods of controlling these weeds include chemical agents and mechanical means. Mechanical control involves manual weeding, which is time consuming and unpleasant work, aggravated by health hazards associated with handling of these weeds. Several attempts have been made to restrict the spread of Parthenium and Lantana in a beneficial manner i.e. as drugs (Singh \& Beck, 2006), green manure (Kishor et al., 2010), energy production (Singh \& Garg, 2014), pesticides (Kaur et al., 2016). These weeds have a high organic content and their disposal and management is necessary for land restoration to maintain soil fertility through solid waste management practices in agriculture. The present study is an attempt to explore the feasibility of Lantana and Parthenium as a substrate for vermicomposting using Eisenia fetida (Savigny, 1826) and to find out the most appropriate ratio of substrate and cow dung for vermicomposting. The nutrient concentration of the compost is also analysed to get an idea about further use of the compost in agricultural practices.

\section{Materials and Methods}

\subsection{Collection of Weeds and Earthworm}

The complete methodology is shown in Figure 1. Fresh cow dung was collected from a nearby farmer, while Parthenium was collected from the Birla Institute of Technology campus near the Patna Airport. Lantana and Parthenium were collected from the Tarumitra Ashram at Digha Ghat, Patna. The earthworm Eisenia fetida was obtained from JAPANI Pharma, a sister institution of the Indian Council of Agriculture and Research (ICAR), Ara, Bihar. The collected weeds were chopped into small pieces $(3-4 \mathrm{~cm})$ to provide more surface area that would facilitate the microbial activity as well as to increase the moisture content. At first, Lantana and Parthenium were mixed in the 1:1 ratio. The weed mixture was mixed in a different ratio with cow dung (Table 1). In the present study, five plastic crates were used as vermin pits and loaded with the Lantana + Parthenium mixture and cow dung in different ratios.

Table 1. Ratio of weeds and cow dung in every pits

\begin{tabular}{|c|c|c|}
\hline $\begin{array}{c}\text { Sample } \\
\text { code }\end{array}$ & Weeds \% & Cow dung \% \\
\hline A & 0 & 100 \\
\hline B & 20 & 80 \\
\hline C & 40 & 60 \\
\hline D & 60 & 40 \\
\hline E & 80 & 20 \\
\hline
\end{tabular}

\subsection{Experimental Setup}

The vermicompost pit was designed using plastic crates with the following dimensions: $48 \mathrm{~cm}$ length, $30 \mathrm{~cm}$ width, $26 \mathrm{~cm}$ depth, and $7 \mathrm{~cm}$ free board, and initial (empty) weight of $2 \mathrm{~kg}$. The drainage system was designed as to properly remove excess moisture from the pit by using sand and gravel up to $3 \mathrm{~cm}$ height from the bottom. Holes were made at the one end of a crate and 2-degree slope was provided to collect leachates during the composting period. Both weeds, Parthenium and Lantana, were mixed in the equal ratio $(1: 1)$ but different ratios were applied when mixing waste and cow dung i.e. $20 \%$ of weed mixture and $80 \%$ of cow dung, $40 \%$ of weed mixture and $60 \%$ of cow dung, $60 \%$ of weed mixture and $40 \%$ of cow dung, $80 \%$ of weed mixture and $20 \%$ of cow dung and $100 \%$ of cow dung. The final weight of the mixture was $10 \mathrm{~kg}$ in all individual pits. The mixture was left for three days to establish and settle, and thereafter 100 specimens of E. fetida were added into each pit. The temperature and weight of each 
pit were measured before introducing the earthworms. The growth of the earthworm was observed and after 50 days another 125 earthworms were added to each of the compost pits (Fig. 1).

\subsection{Nutrient analysis}

A well-homogenized sample was collected from the vermin pit after 45, 60 and 90 days and the nutrient concentration and physical parameters, including temperature, $\mathrm{pH}$ and conductivity, were determined. The $\mathrm{pH}$ and EC were determined using a digital $\mathrm{pH}$ meter Eco tester $\mathrm{pH} 1$ and a digital EC meter (Eco tester EC low), respectively. Temperature, which is one of the most important factors affecting the rate of vermicomposting, was recorded after 15 days using a portable thermometer. Nutrients, i.e. total organic matter, phosphate, nitrate, sodium and potassium, were analysed in the lab using standard methods of determination described in APHA (1998). Organic carbon was analysed using the Walkley and Black method and organic matter was calculated by the following equation:
$\%$ Carbon $=(B-S) \times 0.5 \times 12 \times 100 /$ weight $(\mathrm{gm})$ of sample $\times 4000$ eq. 1

$\%$ Organic matter $=\%$ of total organic carbon $\times 1.72 / 0.58$

eq. 2

(where $\mathrm{B}=$ amount of titrant used by a blank and $\mathrm{S}=$ amount of titrant used by a sample).

Total phosphorus in compost was determined by the ascorbic acid method (APHA, 1998) using a spectrophotometer (Systronics Visible-Spectro 105). Absorbance of a sample was calculated at $650 \mathrm{~nm}$ and the concentration was estimated using a standard calibration curve. Phosphorus concentration was calculated by dividing the atomic weight of phosphorus by the molecular weight of phosphate. The concentration of sodium and potassium was measured using a flame photometer (Systronics flame photometr128), while total nitrogen was estimated using the Kjeldahl method (Bremner \& Mulvaney, 1982). TKN is the sum of ammonia and organic nitrogen present in a sample.

\section{Material used: \\ a) Parthenium and Lantana as raw material. \\ b) Plastic caret to prepare compost pit. \\ c) Eisenia fetida as the earthworm species.}

\section{Design of Pit:}

Preparation of vermicomposting pit by using plastic caret as pit, sand and gravel to design drainage system.

\begin{tabular}{|l|}
\hline \multicolumn{2}{|l|}{ Preparation of raw material: } \\
a. $\quad 100 \%$ cow dung. \\
b. $\quad 20 \%$ weed mixture $+80 \%$ cow dung \\
c. $\quad 40 \%$ of weed mixture and $60 \%$ of cow dung. \\
d. $60 \%$ weed mixture and $40 \%$ cow dung. \\
e. $80 \%$ weed and $20 \%$ cow dung.
\end{tabular}

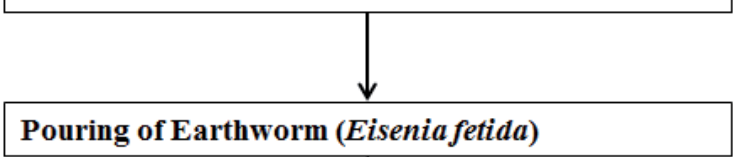

\section{Collection and Analysis:}

Samples has been collected after preparation of the compost and the major nutrient concentration has been analyzed after 45,60 and 90 days.

Figure 1. Detailed flow diagram of methodology adopted 


\section{Results and discussion}

Vermicomposting is an aerobic process of organic waste decomposition in which $\mathrm{pH}$ of the substrate decreases gradually. The $\mathrm{pH}$ value during vermicomposting depends on the time of decomposition and the rate at which different substrates are decomposed. A gradual $\mathrm{pH}$ decrease after 45, 60 and 90 days was observed and the $\mathrm{pH}$ value was $8.1,8.1$ and 7.5, respectively, for pit A. Similarly, $\mathrm{pH}$ of a sample from pit $\mathrm{B}$ was $8.7,8.3$, and 7.7. Whereas $\mathrm{pH}$ of a sample from pit $\mathrm{C}$ was $8.2,8.3$, and 7.3 , while $\mathrm{pH}$ of a sample from pit D and $\mathrm{E}$ was 8.6, 8.4, 7.4 and 8.2, 7.9 and 7.9, respectively after 45, 60 and 90 days (Fig. 2 ). The vermicomposting process caused high reduction in $\mathrm{pH}$ compared to composting due to the production of $\mathrm{CO}_{2}$ and other organic acids. Similar results were reported for vermicomposting of other substrates (Gupta \& Garg, 2008; Suthar, 2009).

It has also been suggested that mineralization of nitrogen and phosphate into nitrate/nitrite and orthophosphate or bioconversion of organic acid into the intermediate species of organic acid might also be responsible for the reduction in $\mathrm{pH}$ values (Suthar, 2009 ). EC of the vermicompost varies over time and depends on the cow dung concentration. An increase in EC is observed in all treatments with the passage of time (60 days) and the increasing amount of cow dung. The maximum increase was observed in container A where the EC value increased by $450 \mu \mathrm{S}$ relative to the initial value recorded on the 45 th day of the culture (Fig. 2). EC values indicate that the rate of mineralization and salt formation was higher in those pits where the amount of cow dung was high. The increasing EC value over time indicates a large amount of salt after the activity of worms (Garg \& Yadav, 2011).

The decrease in the organic matter concentration in all treatments indicates the loss of carbon from the substrate during vermicomposting. Earthworms modify the substrate conditions which consequently promotes the loss of carbon in the form of $\mathrm{CO}_{2}$ or sometimes mineralization of organic matter (Elvira et al., 1998; Kaushik \& Gark, 2003). The overall reduction in total organic carbon after 90 days was $52.1 \%, 62.1 \%, 54.7 \%, 63.7 \%$ and $51 \%$ (respectively) in every pit compared to its value after 45 days (Fig. 2). Reduction in the organic matter depends on the substrate characteristics and the type of substrate used. A significant reduction $(44.65 \%)$ in the organic matter concentration was found in vermicomposting of paper mill waste (Kaur et al., 2010). The total nitrogen content of the vermicompost increases in all pits and the maximum increase was observed in pit $\mathrm{C}$, which had $40 \%$ of the substrate and $60 \%$ of cow dung (Fig. 2). The total nitrate concentration depends on the initial feed material and the degree of decomposition. The loss of organic carbon, the decrease in $\mathrm{pH}$ and mine- ralization of the organic matter containing proteins along with the conversion of ammonium nitrogen into nitrate may be responsible for the increased content of nitrogen in vermicompost (Garg \& Gupta, 2011).

Phosphorus concentration in vermicompost was found to increase with time. The maximum increase was observed in pit $\mathrm{C}(2.7 \mathrm{~g} / \mathrm{kg})$ while the minimum increase $(0.1 \mathrm{~g} / \mathrm{kg})$ in the concentration of phosphorus was found in pit $\mathrm{B}$ after 90 days (Fig. 2). A decrease in phosphorus concentration was found in pit B between 60 to 90 days. An increase in phosphorus concentration in vermicomposting may be due to mineralization and mobilization of phosphate present in the feed material, due to bacterial and faecal activities of earthworms (Garg \& Yadav, 2011). It has been observed that during vermicomposting, earthworms converted the insoluble phosphorus into soluble forms with the help of phosphorus solubilizing microorganisms through phosphatases present in their gut, making it more available for plants (Ghosh et al., 1999). The increase in phosphate concentration during vermicomposting may be due to the presence of alkaline phosphatases in the worm casts.

The concentration of potassium in different pits increased significantly. The maximum increase in the concentration of potassium was found in pit B, while a slight decrease in the overall concentration of potassium was observed in pit $\mathrm{C}$ (from 10.71 to $10.7 \mathrm{~g} / \mathrm{kg}$ ). In pit $\mathrm{A}$ and $\mathrm{B}$, the concentration of potassium increased between 60 to 90 days, while in other pits the concentration of potassium decreased after 60 days (Fig. 2). Agro-industrial waste showed an increase in the concentration of potassium during the vermicomposting (Suthar, 2009). The concentration of sodium after vermicomposting of weeds increases with time. The maximum increase was observed in pit A where the concentration of sodium increased by $34.5 \mathrm{~g} / \mathrm{kg}$, while the minimum increase was observed in pit B $(14.45 \mathrm{~g} / \mathrm{kg})$.

The $C: N$ ratio decreases after vermicomposting. The maximum decrease in the $C: N$ ratio was found in pit $A$, while the minimum decrease was found in pit $B$. The $C: N$ ratio is the most widely used index for the maturity of organic wastes and indicates the degree of decomposition of organic material. During decomposition, more carbon is lost to the atmosphere, which reduces the C:N ratio (Sinha et al., 2011). Wood debris, dry leaves, straw, paper and garden mulch are characterised by a high content of carbon and a smaller content of nitrogen, which is reduced after decomposition. The loss of $\mathrm{CO}_{2}$ in the process of respiration and production of mucus and the nitrogenous excrements are responsible for the decrease in the $\mathrm{C}: \mathrm{N}$ ratio (Garg \& Yadav, 2011; Garg \& Gupta, 2011).

The C:P ratio of the vermicompost decreased with time. The maximum decrease in the $\mathrm{C}: \mathrm{P}$ ratio was found in pit $\mathrm{B}$, while the minimum decrease was found in pit $\mathrm{E}$. 

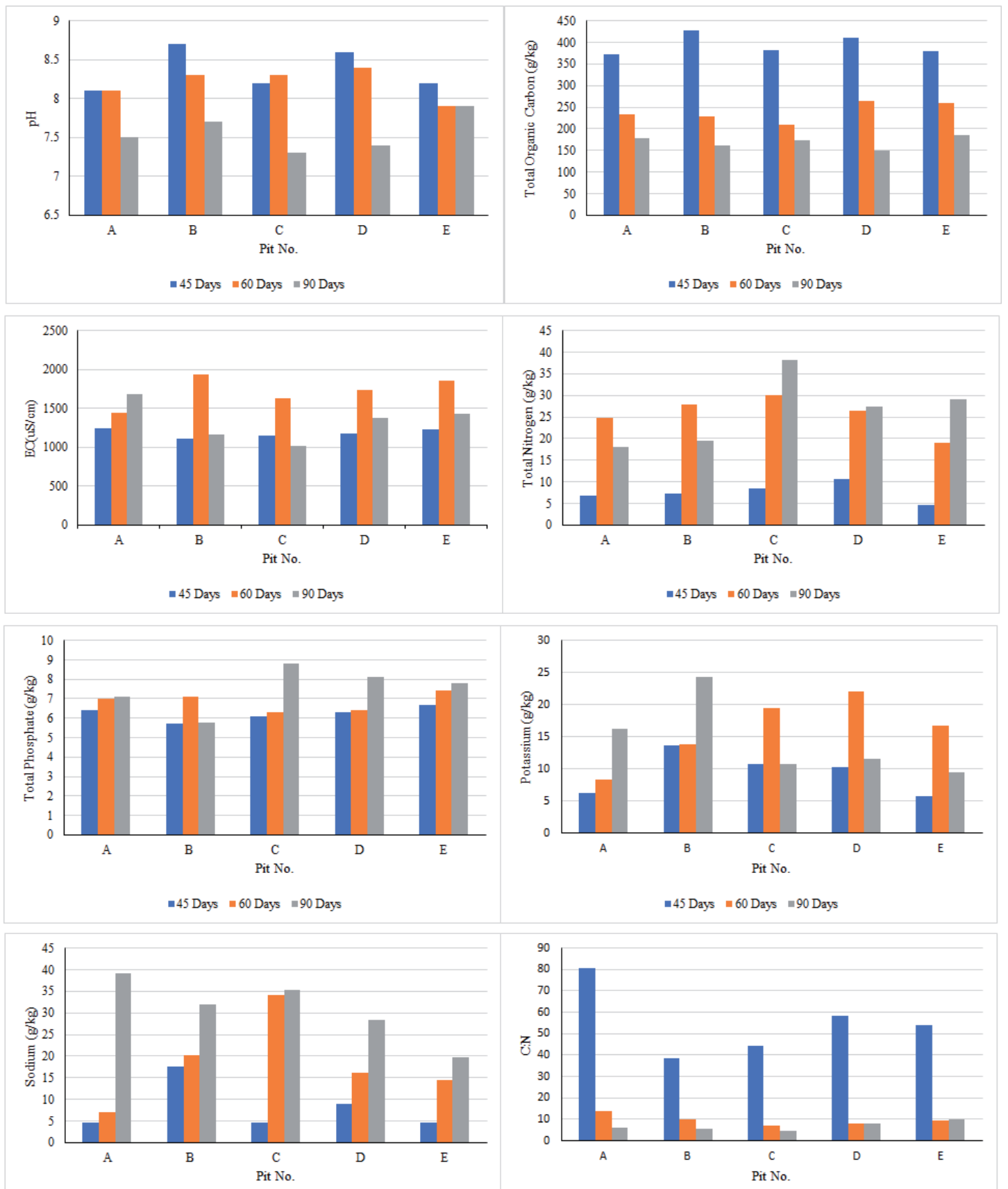

$\| 45$ Days $=60$ Days $=90$ Days

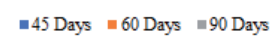

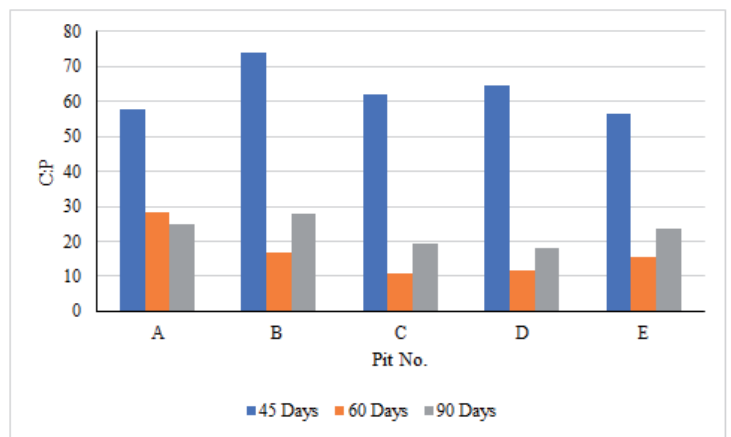

Figure 2. Comparison of physicochemical parameters in different pits 


\section{Conclusion}

There is a possibility of preparing vermicompost by using a proper ratio of Lantana and Parthenium to tackle the problem of these weeds for sustainable management of agriculture. An adequate mixture of weeds and cow dung may provide a sustainable option for management of these terrestrial weeds. Designing a pit is the most important stage in the production of vermicompost. Proper monitoring of temperature and moisture content is required for vermicomposting, and it can be done by laying a proper drainage system. It has been found that the concentration of nutrients, the growth of earthworms, and the compost granules in pit $\mathrm{C}$ were better compared to other pits designed during this study. The maximum growth of earthworms was found in pit C containing $40 \%$ of weeds and $60 \%$ of cow dung. The vermicompost was nutrient rich, odour free and more stable compared to the initial value. The result of the present study indicates economic utilization of Parthenium and Lantana by vermicomposting and its use for ecological engineering and sustainable agriculture. The study shows that Parthenium and Lantana can be used as a substrate material in small- and large-scale vermicomposting field experiments.

\section{Acknowledgments}

The study was conducted indoors and therefore we would like to acknowledge the laboratory staff at the Central University of Bihar.

\section{References}

Akter A. \& Zuberi M.I., 2009, Invasive alien species in Northern Bangladesh: identification, inventory and impacts. International Journal of Biodiversity and Conservation 15: 129-134.

APHA, 1998, Standard Methods for the Examination of Water and Waste Water, 20th Edition. American Public Health Association, Washington DC.

Bremner J.M. \& Mulvaney C.S., 1982, Nitrogen-Total, [in:] Methods of Soil Analysis, 2nd Edition, A.L. Page, R.H. Miller, D.R. Keeney (eds). Agronomy Monograph. 9: 595-624.

Deshmukhe P.V., Hooli A.A. \& Holihosur S.N., 2011, Effect of Lantana camara (L.) on growth, development and survival of tobacco caterpillar (Spodoptera litura Fabricius). Karnataka Journal of Agricultural Science 24: 137-139.

Elvira C., Sampedro L., Benitez E. \& Nogales R., 1998, Vermicomposting of sludges from paper mill and dairy industries with Eisenia andrei: a pilot scale study. Bioresource Technology. 63: 205-211.

Ganesh P.S., Sanjeevi R., Gajalakshmi S., Ramasamy E.V.\& Abbasi S.A., 2008, Recovery of methane-rich gas from solid-feed anaerobic digestion of ipomoea (Ipomoea carnea). Bioresource Technology 99: 812-818.

Garg V.K. \& Gupta R., 2011, Optimization of cow dung spiked pre-consumer processing vegetable waste for vermicomposting using Eisenia fetida. Ecotoxicology and Environmental Safety 74: 19-24.

Garg V.K. \& Yadav A., 2011, Industrial wastes and sludges management by vermicomposting. Rev. Environ. Sci. Biotechnol. 10: 243-276.

Ghisalberti E.L., 2000, Review Lantana camara. Fitoterapia 71: 467-486.

Ghosh M., Chattopadhyay G.N. \& Baral K., 1999, Transformation of phosphorus during vermicomposting. Bioresource Technology 69: 149-154.

Gupta R. \& Garg V.K., 2008, Stabilization of primary sludge during vermicomposting. J. Hazard. Mater. 153(3): 1023-1030.

Kaur M., Aggarwal N.K. \& Dhiman R., 2016, Antimicrobial activity of medicinal plant: Parthenium hysterophorus L. Research Journal of Medicinal Plants 10: 106-112.

Kaur M., Aggarwal N.K., Kumar V. \& Dhiman R., 2014, Effects and management of Parthenium hysterophorus: a weed of global significance. Internatinal Scholarly Research Notices 2014: 1-12. (http://dx.doi. org/10.1155/2014/368643).

Kaur A., Singh J., Vig A.P., Dhaliwal S.S. \& Rup P.J., 2010, Cocomposting with and without Eisenia fetida for conversion of toxic paper mill sludge to a soil conditioner. Bioresource Technology 101: 8192-8198.

Kaushik P. \& Garg V.K., 2003, Vermicomposting of mixed solid textile mill sludge and cow dung with epigeic earthworm Eisenia foetida. Bioresource Technology 90: 311-316.

Kishor P., Maurya B.R. \& Ghosh A.K., 2010, Use of uprooted Parthenium before flowering as compost: a way to reduce its hazards worldwide. International Journal of Soil Science 5: 73-81.

Lakshmi C. \& Srinivas C.R., 2007, Parthenium: A wide angle view. Indian Journal of Dermatology, Venereology and Leprology 73: 296-306.

Love A., Babu S. \& Babu C.R., 2009, Management of Lantana, an invasive alien weed, in forest ecosystems of India. Current Science 97(10): 1421-1429.

Mello F.B., Jacobus D., Carvalho K. \& Mello J.R., 2005, Effects of Lantana camara (Verbenaceae) on general reproductive performance and teratology in rats. Toxicon. 45(4): 459-466.

Misra L. \& Laatsch H., 2000, Triterpenoids, essential oil and photo-oxidative $28 \rightarrow$ 13-lactonization of oleanolic 
acid from Lantana camara. Phytochemistry 54: 969974.

Morin L., Reid A.M., Sims-Chilton N.M., Buckley Y.M., Dhileepan K., Hastwell G.T., Nordblom T.L. \& Raghu S., 2009, Review of approaches to evaluate the effectiveness of weed biological control agents. Biological Control. 5: 1-15.

Nguyen T.L.T., Navie S.C \& Adkins S.W., 2010, The effect of parthenium weeds (Parthenium hysterophorus L.) on plant diversity in pastures in Queensland, Australia, [in:] Proc.17th Australasian Weeds Conf., Christchurch, New Zeland - "New Frontiers in New Zealand: Together we can beat the weeds", S.M. Zydenbos (ed.). New Zealand Plant Protection Society, Auckland: 138

Osunkoya O.O. \& Perrett C., 2010, Lantana camara L. (Verbenaceae) invasion effects on soil physicochemical properties. Biol. Fertil. Soils. [DOI 10.1007/s00374010-0513-5].

Patel S., 2011, Harmful and beneficial aspects of Parthenium hysterophorus: an update. 3 Biotechnology 1(1): $1-9$.

Reinhardt C.F., Belz R.G. \& Hurle K., 2009, Role of the allelochemical parthenin in the invasive strategy of the alien plant Parthenium hysterophorus L. South African Journal of Chemistry 75: 417-418.

Sharma O.P., 1984, Review of the biochemical effects of Lantana camara toxicity. Veterinary and Human Toxicology 26: 488-493.
Sharma O.P., Makkar H.P.S. \& Dawra R.K., 1988, A review of the noxious plant Lantana camara. Toxicon 26: $975-987$.

Sharman. M., Persley D.M. \& Thomas J.E., 2009, Distribution in Australia and seed transmission of Tobacco streak virus in (Parthenium hysterophorus L.). Plant Disease 93: 708-712.

Singh M.N. \& Beck M.H., 2006, Parthenium contact sensitivity travels to the U.K. British Journal of Dermatology 155: 847-848. [DOI 10.1111/j.13652133.2006.07444.x].

Singh R.K. \& Garg A., 2014, Parthenium hysterophorus L. - Neither noxious nor an obnoxious weed. Indian Forester 140: 1260-1262.

Sinha R.K., Valani D., Chouhan K. \& Agarwal S., 2011, Embarking on a second green revolution for sustainable agriculture by vermiculture biotechnology using earthworms: Reviving the dreams of Sir Charles Darwin. Journal of Agricultural Biotechnology and Sustainable Development 2(7): 113-128.

Suthar S., 2009, Bioremediation of Agricultural Wastes through Vermicomposting. Bioremediation Journal 13(1): 21-28.

Yadav A. \& Garg V.K., 2011, Vermicomposting - An effective tool for the management of invasive weed Parthenium hysterophours. Bioresource Technology 102: 5891-5895. 